\title{
Contemplative Transformations: A Blueprint for Creating Culture of Care Learning Environments
}

\author{
Robert Dion Sortino \\ Cal Poly Pomona
}

A qualitative data research approach was used to collect data using the phenomenological research method in an attempt to illuminate the voices of leaders indicating that spirituality was an underpinning influencing their decision-making to create positive school culture. In-depth, semi-structured interviews of six administrators from different ethnic backgrounds and diverse educational programs were conducted. An analysis of the data revealed a rich and thick description of how the six participants relied on contemplative practices to find wisdom and guidance to make sound moral and ethical decisions to create nurturing learning environments at their schools by improving school climate and culture.

\section{INTRODUCTION}

There is a crisis in public education. The gaps of inequity continue to increase for students living and attending schools in impoverished neighborhoods (Center for Public Education [CPE], 2016; MusuGillette et.al, 2016). As a result, there is an urgency for reform (Fullan 2010; Kozol, 2012; Muhammad, 2009). A critical component in reforming our urban schools involves principals committed to improving school climate and culture (Jones \& Shindler, 2016; Noddings, 2013; Thapa, Cohen, HigginsD'Alessandro \& Guffey, 2012).

Recently, there has been a call to develop leaders with the wisdom to make strong moral and ethical decisions to solve these complex challenges in our public schools (Council of Chief State School Officers [CCSSO], 2008; California Professional Standards for Educational Leaders [CPSEL], 2014; Commission on Teacher Credentialing [CTC], 2011; National Education Association [NEA], 2015). Consequently, some research indicates that an effective way to develop leaders capable of making strong moral and ethical decisions is by empowering them to tap into their spirituality (Dantley, 2005a; Fullan, 2010; Houston, 2002) to find the courage to transform school climate and culture in our urban schools.

\section{Inequities in Public Education}

Although it was over three decades ago, Kozol (2012) wrote in his book, quoting James Squires from the Chicago Tribune, "it took an extraordinary combination of greed, racism, political cowardice, and public apathy...for public schools to...get so bad" (p. 72). Unfortunately, the inequalities that were outlined in Kozol's (2012) book, Savage Inequalities, continue to persist today (Musu-Gillette et al., 2016). In fact, a recent analysis of current educational data, according to the National Education Association (NEA) explained, "achievement gaps are an all-too-present reality in today's educational landscape... Disparities in educational outcomes related to poverty, English language proficiency, 
disability, and racial and ethnic background [continue to] persist" (NEA, 2015, p. 1). In addition, the NEA (2015) reported that the 2013 National Assessment of Educational Progress (NAEP) test scores for students of color in the fourth and eighth grades "scored significantly lower than their white peers in reading and math" (p. 4). In addition, according to Musu-Gillette et al. (2016) dating from 1992-2013, the average reading scale scores for Black and Hispanic students in the $12^{\text {th }}$ grade has steadily declined. Furthermore, it has been recently reported by the NEA (2015) that there are an "estimated 46 million children affected by violence, crime, abuse, or psychological trauma in a given year-almost two out of every three children in the U.S.- represent[ing] a large presence in America's public schools" (p. 5). Also, the Center for Disease Control (2015) reported, "in 2012, 4,787 young people aged 10 to 24 years were victims of homicide... Over 599,000 young people aged 10 to 24 years had physical assault injuries treated in U.S. emergency departments" (p. 1). Additionally, the National Education to End Homelessness (2015) reported, "it is commonly estimated that 100,000 children are victims of commercial sexual exploitation each year" (p. 1).

Furthermore, Musu-Gillette et al. (2016) pointed out that drop-out rates, suspension rates, expulsion rates, and children being retained in elementary classes, continue to be much higher for children of color attending our urban public schools in the United States than their white counterparts because of the trauma many of these children face on a daily basis. This daily physical, emotional, and psychological trauma that many of our children face in our urban public schools has had a devastating effect on their equitable access to education. In fact, the NEA (2015) noted, "chronic stress caused by adverse childhood experiences (ACEs) can have permanent effects on the chemical and physical structures of a child's brain" (p. 5). Because there is a potential impact on brain development, and social functioning of children who are exposed to traumatic experiences, which effects their ability to learn and engage in school, addressing this issue must become a focus for our educational system (McInerney \& McKlindon, 2014).

\section{School Climate and Culture}

Improving school climate and culture (Jones \& Shindler, 2016) through the development of empathy could be key in bridging the gaps of inequity that still exists (Noddings, 2015). According to Habegger (2008), "positive school culture is at the heart of improvement" (p. 42). In fact, Jones and Shindler (2016), after examining the connection between school climate and student achievement in 21 urban schools confirmed that there is a "strong relationship between the quality of school climate and academic achievement levels" (p. 5). Recently research indicates that there is a link to schools having a positive school climate and culture with increased student achievement and outcomes (Cohen et al., 2009; Fenzel, \& O'Brennan, 2007; O'Brennan, \& Bradshaw, 2014; Thapa, et al., 2013). When schools focus on climate and culture it has been proven that this positively effects student engagement, safety and environment which is all linked to school achievement (O'Brennan \& Bradshaw, 2014).

In addition, Thapa et al. (2012), explained, "positive and sustained school climate" (p. 11) is directly linked to increased academic achievement, graduation rates, and reduced teacher attrition. Furthermore, Jones and Shindler (2016), argued that school climate and the student achievement connection has been "well-established in the research" (p. 1)

\section{Moral and Ethical Leadership}

According to Morgan, Salomon, Plotkin, and Cohen (2014), school principals need to focus on creating a positive and welcoming school climate and culture. It is important for principals to enact the integrity and courage to address inequitable discipline policies, increase student engagement, and challenge teacher deficit mindsets as one of the ways to positively effect school achievement and outcomes (Morgan et al., 2014). Furthermore, Ishimaru (2013) declared that the key to addressing the persistent inequities in low-income urban schools is educational leadership. Because leadership is so critical in school improvement efforts (Ishimaru, 2013), the National Policy Board for Educational Administration (NPBEA) declared the "goal must be to have a...great principal in every school" (NPBEA, 2015, p. 9). As a result, the 2015 National Standards for Educational Administration (NSEA) has recently been "recast with a stronger, clearer emphasis on...foundational principles of leadership" 
(NPBEA, 2015, p. 2) to ensure that all students are being better prepared for the $21^{\text {st }}$ century. Therefore, an emphasis on building foundational principles of leadership is directly addressed through Standard 2, which stated that effective leaders must "act ethically and professionally in personal conduct, relationships with others, [and] decision-making" (NPBEA, 2015, p. 9). Therefore, understanding the influences on school administration's foundational principles of leadership is important (Fullan, 2010). As a result, one of these critical leadership influences is spirituality (Houston, 2002; Houston \& Sokolow, 2006).

\section{Spiritual Leadership}

In his article, Why Spirituality and Why Now, Houston (2002) spoke about the fact that today's educators operate in a world of chaos and that it is the effective educational leader who taps into their "higher levels of spirit" (p. 6) to find order and purpose to more effectively lead. Hooper-Atlas (2002), in her qualitative research of six principals serving in urban schools in Milwuake discovered, "spirituality influenced the participants' decision-making by giving them courage to make difficult decisions and by providing them guidance in the direction their schools should take" (p. 145).

In these uncertain and chaotic times, where the equity gap continues to widen, the leader who relies not only on their logical and emotional reasoning abilities, but also the leader who includes their spiritual capacity to make decisions, may be better equipped to make more holistic ethical and moral decisions to initiate positive change in school reform efforts (Kulkarni \& Amale, 2015; Zohar, 1997) to effect school climate and culture.

Furthermore, in an ongoing attempt to bridge the achievement gaps and to develop higher quality training programs to better prepare emerging educational leaders for the new millennium, the Commission on Teacher Credentialing (CTC) added a second level to the administrative credential structure because school practices and priorities have changed, thus the expectations for California school administrators has needed to evolve (CTC, 2011). As a result, Standard 14 was created, which calls for educational leaders to develop and model a "personal code of ethics" (CTC, 2011, p. 39). This personal code of ethics and leadership capacity includes such qualities as: "integrity, justice, and fairness [demonstrating] skills in decision-making, [and] problem solving" (CTC, 2011, p. 39) among other leadership competencies. As a result, what Sorvaag (2007) suggested as one possible solution to what Noguera (2003) explained as a crisis of opportunity for students in urban centers, was that "our schools need principals with a strong sense of spirituality" (p. 53), who can model strong ethics and make sound moral decisions to lead urban reform through "critical self-reflective" practices (Dantley, 2005, p. 42) focusing an emphasis on school reform as it relates to school climate and culture (Musu-Gillette et al., 2016).

\section{Separation of Church and State}

As researchers have begun to identify the role of spirituality in helping leaders solve problems and make solid ethical and moral decisions in the field of education (Dantley, 2010; Gieseke, 2014; Houston, 2002; Kheswa, 2016; Macon, 2014; Sorvaag, 2007) a question surfaces: what about separation of church and state? Goldman and Boylan (2010) explained that this provision requiring separation of church and state is known as the Establishment Clause. The Establishment Clause can be identified when "it engages in religious indoctrination, or religious discrimination" (Goldman \& Boylan, 2010, p. 3). In fact, Lofaso (2009) argued, "The Establishment Clause prohibits public schools and their officials from acting in ways inconsistent with the now-famous, three-part Lemon test, named after the Supreme Court case that first articulated that standard" (p. 12). Lofaso (2009) suggested that under the Lemon test, the actions of educators, "(1) must have a primary secular purpose; (2) must have primary effects that neither advance nor inhibit religion; and (3) must not result in excessive entanglement with religion" (p. 12). In addition, the First Amendment stated: "Congress shall make no law respecting an establishment of religion or prohibiting the free exercise thereof" (National Archives, 2017, p. 1). Therefore, it important to understand "spirituality and religion are two distinct constructs so that although spirituality in the 
workplace is a completely justified and appropriate issue of discussion, religion in the workplace is a divisive factor and ultimately out of bounds" (Haynes, 1990, p. 74).

As discussed earlier, spirituality is understood in the context of one's own moral-values, beliefs, and actions (Fry, 2003; Hildebrant, 2011) with no intention of infringing upon another's beliefs, while religion is a set of beliefs and convictions (Ali, 2011; Bible, 1996; Diskul, 1970; Schnittjer, 2010; Satchidananda, 2000) where the primary objective is often to proselytize others. Therefore, because of this, although proselyting a specific religion has no place in the educational workplace, Bertrand (2003) explained there should be an exploration of "spirituality in education" (p. 67), to help educational leaders' mature in their moral professionalism, character, competence, and conduct (Gibson, 2014). Despite the controversial nature of the concept of blending spirituality and education, there has recently been a growing interest in how these two concepts merge as demonstrated through a search of Google Books Ngram Viewer (2016). (see Figure 1).

\section{FIGURE 1 \\ THE INCREASE IN THE NUMBER OF BOOKS WRITTEN FROM 1930-2016 ON CONNECTING SPIRTUALITY AND EDUCATIONT}

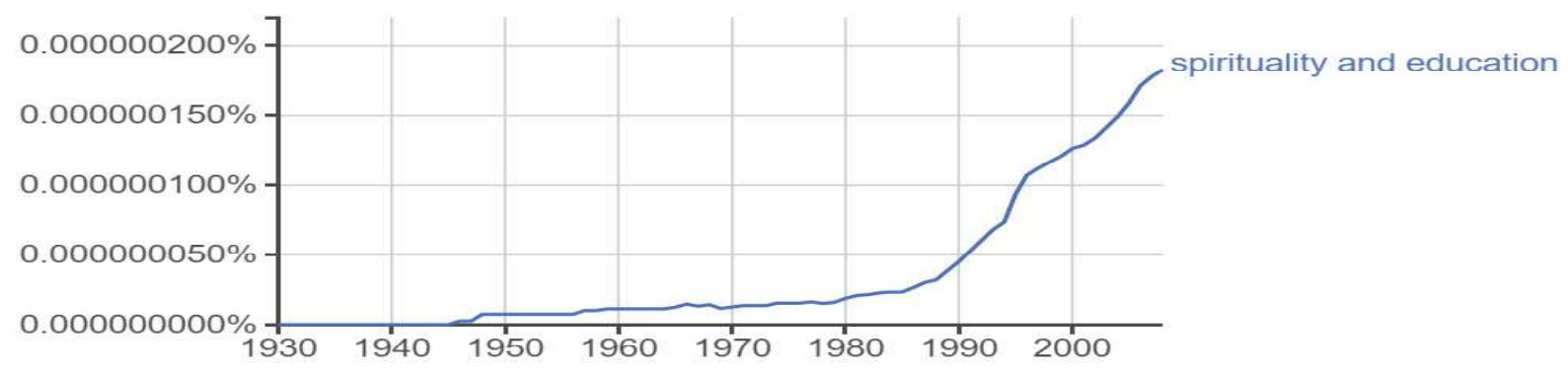

While the discussion about the first amendment and the separation of church and state will continue to be debated as it applies to students and education (Goldman \& Boylan, 2010; Lester \& Roberts, 2006), there is a call for educational leaders to be moral leaders who develop nurturing learning environments by promoting a strong code of ethics for students through personal modeling of the expected behaviors (Brown, 2014).

\section{Spirituality in Brain and Genetic Research}

Recently, Sisk (2015) pointed out that there are numerous scientists who have done extensive research in brain science as it applies to spirituality,

Candace Pert (1997); geologist Greg Braden (1997); physicists Fritjof Capra (1991) and Neils Bohr (1999); and brain researchers Rodolfo Llinas and Ribary Urst (1993), Michael Persinger (1996), and Vilayanur Ramachandran and Sandra Blakeslee (1998); Their work represents the classical role of science, the search for truth in biology, geology, physics, and brain research; and their research helped to build a scientific foundation for spiritual intelligence. (p. 2)

On scans taken with positron emission topography, these neural areas light up whenever research subjects are exposed to discussion of spiritual or religious topics" (Zohar, 1997, p. 11). In other words, when an individual is asked about spiritual matters and has to contemplate these ideas, the brain demonstrates intellectual activity (Zohar, 1997). In addition, Garland and Howard (2009) discovered that there was one area of research that "found significant evidence of mental training leading to neoplastic modifications in brain activity [which] focuses on the study of meditation.... Such intentional mental training has been shown to induce functional neurobiological changes" (p. 193).

Consequently, Zohar (1997), in explaining the viability of spiritual intelligence as supported by brain research, explained that there are three such psychological processes based on: (1) serial neural wiring in the brain, (2) emotional quotient which is based on associative neural wiring in the brain, and (3) spiritual 
quotient which is based on the third neural system in the brain. These three psychological processes are, "synchronous neural oscillations that unify and integrate the data across the brain. The process facilitates interactions between emotions and logic" (p. 66).

In addition, there is more physiological evidence in support of spiritual intelligence, in what Hamer (2005) suggested, that human beings are wired genetically to be spiritual. Hamer (2005) explained this concept by stating: "hardwired into our genes...spirituality... is, in fact, an instinct" (p. 4). Furthermore, Hamer (2005) concluded that humans have approximately 35,000 genes, and of these thousands of genes that each human contains, there has been the discovery of a "specific gene [that is] associated with the self-transcendence scale of spirituality" (p. 11). Finally, according to Seitz, Nickel, and Azari (2006) the meta-analysis testing that was performed on human brain functions revealed that there are six spatially distinct activation clusters in the medial part of the frontal lobe dorsal to the inter commissural plane that are activated in connection to spiritual intelligence.

Therefore, the concept of spirituality as an innate instinct, can be likened to the idea, that just like mothers are hardwired to care for their children, not all do (Parker-Pope, 2008). In addition, Kramer and Enomoto (2014) explained that there seems to be evidence that human beings, whether ancient peoples or modern mankind, seek some sort of higher power through stories, myths, rituals or customs to understand his/her place and purpose in the universe. Whatever the analogy, there seems to be scientific evidence that links spirituality to innate human functioning (Hamer 2005; Garland \& Howard, 2009; Seitz et al, 2006; Sisk, 2015; Zohar, 1997).

\section{Spirituality in the Business Field}

Recently, the business world has discovered the positive impact that spirituality has on business outcomes, in fact, Alumona (2016) explained that with the accelerating rate of change in today's business world, people "feel as though they are unable to achieve a sense of balance and stability" (p. 182) and because of this, business leaders have found that by applying spirituality to decision-making in the workplace, they are able to create that sense of stability and balance for themselves and their employees, which results in workplace productivity and efficiency. In fact, Alumona (2016) concluded in his research that there is a strong positive correlation between the use of spirituality in the workplace and an organization's efficiency and ability to produce results. As a result, Alumona (2016) explained, for this reason, "spirituality influencing organizational decisions has come to stay" (p. 183). Furthermore, Sisk (2015) declared that spiritual intelligence, "is starting to be considered a viable intelligence, and this recognition is being vigorously manifested in the world of business" (p. 1).

Furthermore, in a recent study, data were collected through a structured questionnaire where 26 successful entrepreneurs were questioned about the use of spirituality in the workplace (Kumar \& Muruganantham, 2015, p. 103). In this study, Kumar and Muruganantham (2015) discovered, "there [was] a significant relationship between spirituality and entrepreneurial success" (p. 103). In addition, Singh et al. (2015) in their study of two Fortune 500 Companies, Bharat Petroleum and National Thermal Power Corporation Limited, suggested, "The corporate world is fast waking up to the phenomenon of connecting within as the best means to achieve not only the organization's goals, but also to meet the fastemerging external challenges" (p. 1). Consequently, Singh et al. (2015), added that although it is, "very difficult to measure the immeasurable, but by recognizing the spiritual side of the employee, organizations can have [a] competitive edge over...others" (p. 8). The reason for this competitive edge could be attributed to employees, who if they tapped into their spiritual orientations, would excel in both their personal relationships and their personal outcomes thereby resulting in better organizational productivity (Singh et al., 2015).

In conclusion, Christ-Larkin (2010) explained that the use of spirituality was a "necessary element for organizational leadership success" (p. 135) because the results of the study revealed a positive correlation between transformational leadership success and a leader's spiritual intelligence. Therefore, Crichton (2008) concluded that leaders who incorporated spiritual intelligence into their business activities often led to a changed positive corporate culture which led to improving positive results in manufacturing. 


\section{Spirituality in the Field of Education}

Because of the recent breakthroughs in brain and genetic research as it relates to spirituality, and the success the business world is having in integrating spirituality into the workplace, Dantley (2003) declared, "the educational leadership discourse is being challenged to include a spiritual voice in its conversation" (p. 273). Houston, Blankstein, and Cole (2007) stated that because educational leaders have such a tremendous responsibility in touching the lives of children, especially in our urban centers, these "leaders must be attuned to the third dimension beyond thinking and doing- to what it is to be a human in touch with the divine" (p. 2). Houston and Sokolow (2006) further hypothesized, that there is an "unseen force that is both a part of humankind and at the same time greater than humankind" (p. xxiv). Houston and Sokolow (2006) referred to this connection as spirituality (p. xxiv). Finally, Dantley (2005a) later declared, "Spirituality serves as the very energy we must have to keep marginalized people from falling into paralysis and cynicism" (p. 659). In fact, Dantley (2003) argued, "Leaders who work in schools populated by urban youth must embrace the fact that very often, communities of color are deeply grounded in religious or spiritual contexts" (p. 281). Dantley (2003) therefore, further debated that an educational leader, grounded by spirituality, is not satisfied only with academic achievement on standardized tests, but also feels an ethical obligation on behalf of students to help them develop into "contributing members of society" (p. 282) who take advantage of their educational experience to "become organic intellectuals [who] bring about radical changes in society" (p. 282). Dantley (2005a), therefore, added to his previous discourse by explaining, "the preservation of the sacred self then becomes the focus of those who would be educational leaders in urban schools" (Dantley, 2005a, p. 658), thereby making it imperative that educational leaders rely on spirituality to help inform their decision-making (Dantley, 2005a).

In the past decade, a number of studies have begun to emerge demonstrating the relationship between educational administrators and their use of spirituality to better inform their leadership practices (Beard, 2015; Blanton, 2007; Gieseke, 2014; Kheswa, 2016; Macon, 2014; Reyes, 2015; Robertson, 2008; Sorvaag, 2007). Most recently, Kheswa (2016) conducted a qualitative study of 10 educational leaders in South Africa and found that an individual's internal spiritual development was at the core of effective leadership. Furthermore, Kheswa (2016) discovered in this study that leaders tapping into spirituality had three main commitments: "commitment to God; commitment to personal growth; and commitment to the development of others" (p. 179). In another study, Reyes (2015) examined the role of spirituality in the leadership of three Latino principals in an inner-city school district of Southland Independent School District. What this study revealed was, "Spirituality helps to affirm the principal's identity, [and] incorporates personal values or beliefs with professional decisions and actions" (187). Finally, Reyes (2015) explained, "Based on the analysis of the data.... spirituality is expressed and exercised in these principals' roles" (p. 161).

Furthermore, in a qualitative research study of 10 secondary school principals, working in urban school districts, Moreno (2015) discovered, "spirituality [was] a vital component to [their] successful educational leadership" (p. 97). In fact,

the study found leaders' spirituality had a substantial influence on how they led their educational organizations [and that] this higher power gave [these] leaders a sense of inner peace and fulfillment through their actions and facilitated their own decision processes as educational leaders. (p. 96)

\section{Reflective Practices}

The Council of Chief State School Officers (CCSSO) has called for educational leaders to utilize "self-awareness, reflective practice [and] ethical behavior" (CCSSO, 2008, p. 3-4) to make better informed decisions to lead school reform. Therefore, Dantley's (2005a) argument for making a shift to a moral leadership approach through critical self-reflection, where leaders embrace their "true spiritual selves" (p. 43) could be key in the development of sound decision making. Furthermore, according to Brown (2014), educational leaders must continually examine and reflect upon their "personal assumptions, values, and beliefs" (p. 10) as they consider the needs of the students and staff they serve. In addition, these leaders must also reflect on areas for personal growth, professional learning, proficiency 
skills, and personal motivation as they consider how to make ethical decisions that promote fairness and equity (Brown, 2014).

Furthermore, Weichel and Neal (2014) suggested that educational leaders, who carefully reflect upon their thoughts and actions and "act upon a personal code of ethics" (p. 9) might be better prepared to "strengthen staff trust" (p. 5) which could positively improve school climate and culture. In addition, according to Vaughan (2002), through the practice of contemplation, and personal reflection, leaders can possibly awaken their spirituality to better solve problems.

Therefore, Whitney (2014) suggested that an individual could build spiritual awareness through the practice of silent listening, prayer, and personal reflection through connecting to a Divine Source. In fact, Nasel (2004) suggested that through such practices as prayer, contemplation, self-reflection, meditation, and entering periods of silence or solitude is the best way to solve problems thereby developing his/her spiritual intelligence. In addition, Bansal (2016) agreed that there are several ways an individual could develop their spirituality, through self-reflection, open dialogue, and open-mindedness. Therefore, through the use of contemplative, reflective practices an individual, by "bring[ing] one's life into perspective" (Sisk, 2000, p. 210), could possibly increase an inner knowing, that connects him/her with the Universal Mind to better solve problems.

\section{METHODOLOGY}

The phenomenological approach to conduct research was used for this study because it is a "science of Essential Being...or...eidetic science" (Husserl, 1976, p. 5) or as Merriam (2009) stated, "A phenomenological approach is well suited to studying affective, emotional, and often intense human experiences" (p. 26). Therefore, the purpose of this study was to illuminate the voices of six principals who identified themselves as being educational leaders who tap into their spirituality to make decisions to best guide them to transform their school's climate and culture.

\section{Research Questions}

1. How do these school leaders define spirituality?

2. How does an educational leader's spirituality influence his/her beliefs and values that guide his/her decision making to promote transformational change in school culture?

3. How does spirituality influence the practices and processes that guide educational leaders to promote equity and advocacy in education?

4. How does an educational leader's spirituality support him/her when striving to overcome obstacles towards bringing about change?

\section{Research Design: Phenomenology}

The qualitative approach chosen for this study was what Husserl (1976) referred to as phenomenology or a science of essences study approach. Furthermore, Husserl's (2012) concept of phenomenology leads us back to the source of the experience as well as "transforms the world into mere phenomenon" (p. 240). Moustakas (1994) further explained "what appears in consciousness is an absolute reality" (p. 27). Finally, phenomenology is a type of qualitative research with philosophical roots that emphasize the "study of lived experiences" (Lichtman, 2013, p. 245) or as Merriam (2009) pointed out as "a study of people's conscious experience of their life-world" (p. 24). Therefore, the purpose of this study was to explore and understand the phenomenon of the connection between an educational leaders' approach to spirituality and how this process effected their decision-making as it related to reforming a school's culture (Kaser \& Halbert, 2009; Maitlis \& Christianson, 2014; Walton, 2015). As a result, this study used a phenomenological approach (Husserl, 1976; Lichtman, 2013; Moustakas, 1994), whereby phenomenology's purpose is "the lived experiences of individuals who have experienced a certain phenomenon [and to find] the essence of the phenomenon" (Lichtman, 2013, p. 77). In addition, according to Lin (2013), it is important to use the phenomenological methodology when the study goals are to "explore concepts from new and fresh perspectives" (p. 469). As a result, this researcher chose the 
qualitative approach known as phenomenology as the research design (Husserl, 1976; Moustakas, 1994) due to the unique nature of this very emotional, personal, and intense study of researching the private spiritual practices of educational leaders (Merriam, 2014). The purpose of this study, therefore, was to capture the lived experiences of the participants (Husserl, 1976; Litchman, 2012; Merriam, 2014) as it pertained to their use of spirituality to make decisions about how to initiate reform of their school's culture to address the issues of inequity (Kaser \& Halbert, 2009; Maitlis \& Christianson, 2014; Walton, 2015).

\section{Data Collection}

According to Padilla-Diaz (2015), "The most appropriate data collection strategy for a phenomenological research is the...interview" (p. 104). In an attempt to understand the lived experiences (Husserl, 1976; Litchman, 2012; Merriam, 2014) of the six administrators interviewed for the study, each administrator was interviewed three times, using a semi-structured interview process (Patton \& Cochran, 2002). This researcher used a total of 22 probing questions during the three interviews. The interview questions consisted of seven distinct categories: (1) educational experience, (2) leadership experience, (3) spiritual background, (4) school reform, (5) spiritual practices, (6) clarifications, and (7) recommendations. Each interview lasted between 15-30 minutes. The first two interviews were conducted at the administrator's school, and the final interview was conducted over the phone. The researcher provided each participant with a list of the interview questions prior and during the interview for simplicity of communication and reflection and then this researcher recorded the interview using an iPhone.

\section{Data Analysis}

In analyzing the data, Bednall (2006) said the researcher ought to "allow the voices of subjectivity to emerge authentically" (p. 124). The process of analyzing the data for this study included: using a digital audio recording device during the interviews to record the data (iPhone), translating the recorded interviews in to written transcripts (Transcriptionpuppy.com), reading the transcribed interviews and identifying significant quotes, identifying themes, developing a coding scheme, coding the data (using a codebook and Atlas-ti), and allowing the data to bubble-up until the true essence was understood (Patton \& Cochran, 2002).

The first step in analyzing the data was through the process described by Merriam (2009) as epoché, where the researcher explored his own experiences, in part to examine dimensions of the experience and become aware of personal prejudices, viewpoints, and assumptions. Secondly, according to Lichtman (2013), the next step was the process of bracketing which "involves placing one's own thoughts about the topic in suspense out of question" (p. 80). Prior to conducting the interviews, a conceptual framework was created, using deductive codes, which allowed for the biased themes to surface (setting those ideas aside), and this resulted in the emergence of inductive codes (Lichtman, 2013) or new themes. In addition, Moustakas (1994) further explained that a researcher should practice the process of phenomenological reduction (suspending judgment), where the researcher attempts to gain the essence of experience.

Moustakas (1994) further explained that through the process of horizontalization, the data are laid out, and themes and clusters begin to emerge. Finally, through the final process of imaginative variation (reducing the phenomena into its necessary essences), the researcher arrived at the essence of the phenomena (Merriam, 2014).

\section{FINDINGS}

\section{Contemplative Transformations}

Through this research what emerged as the primary finding was the concept that this researcher defines as: Contemplative Transformations. Contemplation, according to Louth (2007), can be dated as far back as Plato. Hodes (2014), suggested that contemplation "exercises designed to broaden perceptional awareness, [and] decrease emotional drama [can] mobilize strategies for creative problem- 
solving” (p. 1). Contemplative practices can be transformative (Hodes, 2014; Louth, 2007; Merton, 1972). Or, as Merton (1972) explained, these contemplative practices can be described as an experience where a person feels they have "been touched by God" and spoken to in the "depths of [their] own being" (p. 3), thus compelling them to be transformed and act out of gratitude. Finally, according to Hodes (2014), contemplative practices, are a broad set of activities that facilitate a state of calm centeredness and aid in the exploration of meaning and values that "can have a positive impact on problem-solving" (p. 1). Consequently, Hodes (2014) described examples of these contemplative practices as: centering, silence, meditation, visualization, singing, volunteering, deep listening, and spiritual ceremonies.

In this study, it was confirmed that all six principals practiced some form of self-reflection through contemplative practices to aid them in their decision-making. What was revealed through this qualitative research was that all six participants believed that they were empowered to make stronger moral and ethical decisions because of their practice of contemplation. As a result, through the practice of contemplation, each participant explained that their attitudes, perceptions, and passions were transformed. Therefore, through this contemplative transformation, these participants felt compelled to act on behalf of the students they served to improve school climate and culture as a means to address the issues of inequity at their schools.

The six principals in this study described their contemplative transformations as meditation, deepbreathing, centering, essence, grounding, connecting, listening and quietness. The participants identified that through their contemplative transformations they felt a deep connection with God that compelled them to create a culture of care, by having a student-centered mindset, and leading through servanthood.

\section{Relationship with the Divine}

At the heart of spirituality, according to some authors, is a deep and intimate connection with God (Hildebrant, 2011; Houston, et al., 2007; Hyson, 2013). This connection with God first starts with an acute awareness of self-knowledge and then expands to include the Divine (Amram, 2007; Emmons, 2000; King \& DeCicco, 2009; Mayer, 2000). In fact, Merton (1972) posited, "Contemplation is, above all, awareness of the reality of the Source" (p. 1) where both "reason and faith aspire" (p. 1).

In trying to describe this connection they had with God, several of the participants in this study welled-up with tears. In fact, according to the participants, spirituality is based on the influence that God had in his/her life. It was, therefore, through the development of a relationship with God, through contemplative practices, that this became the starting point to provide them with guidance and wisdom to initiate reform.

\section{Culture of Care}

The importance of creating a culture of care, as echoed by all six administrators involved in this study, was what is at the heart of school reform, which is being able to give students an experience where they desire to come to school and feel that they belong. It has been determined "over the past two decades, [that] researchers and educators have increasingly recognized the importance of [improving] K12 school climate [and culture]" (p. 1) as a means to close the gap of inequity. Furthermore, Thapa, et al. (2012), declared that improving, "School climate [and culture] is an important factor in the successful implementation of school reform" (p. 10).

Finally, the participants in this study expressed that it was important to help students realize their potential and to offer their students hope by caring for their individual needs. The participants explained that creating a culture of care on their campuses included encouraging their staff to engage with their students at their school through caring, compassion, grace, and encouragement through positive affirmations, and expectations.

\section{Student-Centered Mindset}

In attempting to address school climate and culture, it is imperative that the focus of all reform efforts is centered around meeting the needs of students (Noguera, 2003; Starratt, 2004, Starratt, 2005a, Starratt, 2005b; Stefkovich \& O'Brien, 2004; Stefkovich, 2013). The participants in this study, explained that 
administrators and staff need to go beyond the minimum in meeting the needs of students, and that every attempt needs to be made to meet the needs of the students they served.

During the interview process, each of the six educational leaders expressed how passionate they were about having a student-centered mindset. All of the participants explained to this researcher, that because of their relationship with God as strengthened through contemplation, they felt compelled to foster a caring environment where students were the focus. Multiple times throughout the interview process, each of the administrators explained how they intentionally fostered this student-centered mindset with their staff. Additionally, the participants spoke about how they model for their teachers this student-centered mindset by greeting students, feeding their students if they were hungry, providing them with clothing, providing professional development to increase teacher empathy as just a few actions they engaged in to create this student-centered mindset.

\section{Servant Leadership}

Finally, according to the participants in this study, servant leadership is an important characteristic of an educational leader who practices spirituality. According to Hyson (2013), servant leadership is the hallmark of all spiritual leaders. In addition, Sergiovanni (1999) explained that an educational leader has the moral responsibility to serve others.

For each of the participants, they felt that they were given guidance to lead their staff and students through servant leadership as they practiced contemplation. The participants explained that as they connected to God through contemplation they were able to set their egos and selfish motivations aside to do what was best for the students and staff they served. These acts of service, as explained by the participants led to trust and collaboration. Through these trusting and collaborative relationships actions were taken to address issues to improve school climate and culture.

\section{CONCLUSION}

Education is a human right (Freire, 1998). All children deserve to sit at the table of education and feast on the riches of knowledge. However, the inequity gap continues to spread like cancer through our urban public-school systems (Musu-Gillette et al., 2016) destroying the very life of our most prized possessions, our children. There is an urgent need for school reform. At the heart of this reform is the need to create caring school climates and cultures (Gruenert, 2008; MacNeil et al., 2009; Stolp \& Smith, 1995; Thapa, et al., 2012). Our schools need to be nurturing learning environments where all students are treated with dignity and respect, a place where they are free to ask questions, study, and dream. This research demonstrated that through contemplative transformations, six educational leaders found the strength to act in caring and compassionate ways towards their staff and students alike, creating caring learning communities. The findings of this study confirmed the research (Dantley, 2005a; Houston, 2004; Magnusen, 2001; Santovec, 2013) that suggested educational leaders tapping into their spirituality through contemplative transformations could be key in aiding reform efforts in improving school climate and culture.

As a result, more research is required in this area to more fully explore the time, frequency, specific practices, and the extent to which these contemplative transformations contributed specifically to their confidence and calmness in making difficult decisions when facing obstacles at work. In addition, research is recommended to identify the exact components of what it means to have a relationship with God. Furthermore, continued brain research could be conducted to locate how the brain responds to these contemplative transformations to determine the correlation between the specific contemplative transformation exercises and their impact on making sound moral and ethical decisions.

Finally, more research is needed in identifying the four key elements (relationship with God, culture of care, student-centered mindset, and servant leadership) in transforming the school climate and culture and to what extent these factors are influenced through contemplative transformations. Finally, more research needs to be done to understand more fully the specific connections that certain contemplative transformations have to each element and the impact this has on school climate and culture. 


\section{REFERENCES}

Ali, M. M. (2011). Holy Quran. Ahmadiyya Anjuman Ishaat Islam. Retrieved from http://bhaktil.ucoz.com/_ld/1/157_Al-Quran-Englis.pdf

Alumona, S. C. (2016). Spirituality and decision-making in industrial organizations: The current views. Global Journal of Applied, Management and Social Sciences. 12(9), 175-185.

Amirkhani, A. H. \& Yosefi, A. S. (2015). The effect of spiritual intelligence on the performance of information system in the organization. Journal of Management Sciences, 1(11), 285-291.

Amram, Y. (2007). What is spiritual intelligence? An ecumenical, grounded theory. (Doctoral dissertation). Retrieved from: http://www.yosiamram.net/docs/what_is_SI_Amram_wrkg_paper.pdf

Bansal, P. (2016). Developing spiritual intelligence: Contemporary practices in teacher education. Retrieved from https://www.academia.edu/7408873/DEVELOPING_SPIRITUAL_INTELLIGENCE_CONTEM PORARY PRACTICES IN TEACHER EDUCATION

Beard, K. S. (2015). Standing in the gap: Theory and practice impacting educational opportunity and achievement gaps. Urban Education. doi: 10.1177/0042085915613553.

Bednall, J. (2006). Epoché and bracketing within the phenomenological paradigm. Issues in Educational Research, 16(2), 123-138.

Bertrand, Y. (2003). Contemporary theories and practices in education. Madison, WI: Atwood Publishing.

Blanton, J. (2007). Exploring spirituality in educational leadership: Toward a leadership framework of critical spirituality (Doctoral dissertation, University of Florida). Retrieved from $\mathrm{http}: / /$ search.proquest.com/openview/1c423c1e3e1feb2344ca 7 cea27568f71/1?pqorigsite $=$ gschola $\mathrm{r} \& \mathrm{cbl}=18750 \& \mathrm{diss}=\mathrm{y}$

Boake, C. (2002). From the Binet-Simon to the Wechsler-Bellevue: Tracing the history of intelligence testing. Journal of Clinical and Experimental Neuropsychology, 24(3), 383-405.

Brown, J. (2014). California Professional Standards for Education Leaders (CPSEL). Retrieved from http://www.ctc.ca.gov/educator-prep/standards/CPSEL-booklet-2014.pdf

California Professional Standards for Educational Leaders (2014). WestEd and the Association of California School Administrators. Retrieved from:

http://www.wested.org/online_pubs/cpsel_standards.pdf

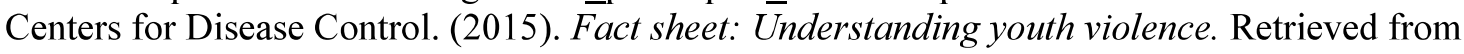
http://www.cdc.gov/violenceprevention/pdf/yv-factsheet-a.pdf

Centers for Public Education (2016). Educational equity: What does it mean? How do we know when we reach it? Retrieved from http://www.centerforpubliceducation.org/educationalequity

Christ-Larkin, H. (2010). A Correlation Analysis of Transformational Leadership and Spiritual Intelligence. (Doctoral dissertation). Available from ProQuest database. (UMI3438390)

Cohen, J., McCabe, L., Michelli, N. M., \& Pickeral, T. (2009). School climate: Research, policy, practice, and teacher education. Teachers college record, 111(1), 180-213.

Commission on Teacher Credentialing (2011). Standards of quality and effectiveness for administrative services credentials. Retrieved from http://www.ctc.ca.gov/educator-prep/standards/SVC-AdminHandbook.pdf

Council of Chief State School Officers (2008). Educational leadership policy standards: ISLLC 2008. Retrieved from: http://www.ccsso.org/Documents/2008/Educational_Leadership_Policy_Standards_2008.pdf

Crichton, J. C. (2008). A qualitative study of spiritual intelligence in organizational Leaders. (Doctoral dissertation). Available from ProQuest database. (UMI3340796)

Dantley, M. E. (2003). Purpose-driven leadership: The spiritual imperative to guiding schools beyond high-stakes testing and minimum proficiency. Education and Urban Society, 35(3), 273-291. 
Dantley, M. E. (2005). Moral leadership. In Fenwick English (Ed.), The sage handbook of educational leadership (pp. 34-46). Thousand Oaks, CA: Sage.

Dantley, M. E. (2005a). Faith-based leadership: Ancient rhythms or new management. International Journal of Qualitative Studies in Education, 18(1), 3-19.

Dantley, M. E. (2010). Successful leadership in urban schools: Principals and critical spirituality, a new approach to reform. The Journal of Negro Education, 79(3), 214-219.

Delaney, M. (2003). The Emergent Construct of Spiritual Intelligence: The Synergy of Science and Spirit. (Unpublished dissertation). Arizona State University, Tempe.

Dewey, J. (1997). How we think. New York, NY: D.C. Heath and Co. Publishers

Diskul, P. P. (1970). The four noble truths and the eightfold path. In F. Dunne (Ed.), In the world religions speak on the relevance of religion in the modern world (pp. 33-38). Netherlands: Springer

Emmons, R. A. (2000). Spirituality and intelligence: Problems and prospects. The International Journal for the Psychology of Religion, 10(1), 57-64.

Emmons, R. A. (2000a). Is spirituality an intelligence? Motivation, cognition, and the psychology of ultimate concern. The International Journal for the Psychology of Religion, 10(1), 3-26.

Fenzel, L. M. \& O'Brennan, L. M. (2007). Educating at-risk urban African American children: The effects of school climate on motivation and academic achievement. Retrieved from http://files.eric.ed.gov/fulltext/ED497443.pdf

Freire, P. (1998). Pedagogy of freedom: Ethics, democracy, and civic courage. Lanham, MD: Rowman \& Littlefield.

Fry, L. W. (2003). Toward a theory of spiritual leadership. The Leadership Quarterly, 14(6), 693-727.

Fullan, M. (2010). The moral imperative realized. Thousand Oaks, CA: Corwin Press.

Garland, E. L. \& Howard, M. O. (2009). Neuroplasticity, psychosocial genomics, and the biopsychosocial paradigm in the 21 st century. Health \& Social Work, 34(3), 191-199.

Gibson, A. (2014). Principals' and teachers' views of spirituality in principal leadership in three primary schools. Educational Management Administration \& Leadership, 42(4), 520-535.

Gieseke, A. R. (2014). The relationship between spiritual intelligence, mindfulness, and transformational leadership among public higher education leaders (Doctoral dissertation). Available from ProQuest database. (UMI3617784)

Goldman, D. \& Boylan, E. (2010). Integrating faith-based organizations into state-funded pre-k programs: Resolving constitutional conflict. Education Law Center. Retrieved from: http://files.eric.ed.gov/fulltext/ED520521.pdf

Goodman, L. A. (1961). Snowball sampling. The annals of mathematical statistics, 148-170. Retrieved from http://projecteuclid.org/download/pdf_1/euclid.aoms/1177705148

Google Books (2016). Ngram Viewer: Spiritual intelligence. Retrieved from https://books.google.com/ngrams/graph?content=spiritual+intelligence\&year_start=1980\&year_e $\underline{\mathrm{nd}}=2016 \&$ corpus $=15 \&$ smoothing $=10 \&$ share $=\&$ direct url $=\mathrm{t} 1 \% 3 \mathrm{~B} \% 2 \mathrm{Cspiritual} \% 20$ intelligence $\%$ $3 \mathrm{~B} \% 2 \mathrm{Cc} 0$

Green, W. N. \& Noble, K. D. (2010). Fostering spiritual intelligence: Undergraduates' growth in a course about consciousness. Advanced Development Journal, 12(1), 26-49.

Gruenert, S. (2008). School culture, school climate: They are not the same thing. Principal Arlington, 87(4), 56.

Guthrie, W. K. C. \& Warren, J. (2012). The Greek philosophers from Thales to Aristotle. London, England: Routledge.

Habegger, S. (2008). The principal's role in successful schools: Creating a positive school culture. Principal, 88(1), 42-46.

Hamer, D. H. (2005). The God gene: How faith is hardwired into our genes. New York, NY: Anchor Books.

Haynes, C. C. (1990). A teacher's guide to study about religion in public schools. Journal of Law and Religion, 8(1/2), pp. 297-308. doi:10.2307/1051286 
Hildebrant, L. S. (2011). Spiritual intelligence: Is it related to a leader's level of ethical development? (Doctoral dissertation). Available from ProQuest database. (UMI3443322)

Hodes, C. (2014). Contemplative practices boost creativity. Cornell Chronicle. Retrieved from http://www.news.cornell.edu/stories/2014/07/contemplative-practices-boost-problem- $\quad$ solving

Hooper-Atlas, B. L. (2002). The role of spirituality in the work of African-American women principals in urban schools. (Unpublished dissertation). University of Wisconsin, Madison.

Houston, P. D. (2002). Why spirituality, and why now? School Administrator, 59(8), 6-8.

Houston, P. D., Blankstein, A. M., \& Cole, R. W. (2007). Spirituality in educational leadership (Vol. 4). Thousand Oaks, CA: Corwin Press.

Houston, P. D. \& Sokolow, S. L. (2006). The spiritual dimension of leadership: 8 key principles to leading more effectively. Thousand Oaks, CA: Corwin Press.

Husserl, E. (1976). Ideas: General introduction to pure phenomenology. New York, NY: Allen \& Unwin; Humanities Press.

Hyson, P. (2013). The spirited leader: The potential of spiritual intelligence to improve leadership. The International Journal of Leadership in Public Services, 9(3/4), 109-115.

Ishimaru, A. (2013). From heroes to organizers: Principals and education organizing in urban school reform. Educational Administration Quarterly, 49(1), pp. 3-51. doi:10.1177/0013161X12448250

Jones, A. \& Shindler, J. (2016). Exploring the school climate-student achievement connection: Making sense of why the first precedes the second. Educational Leadership and Administration, 27, 35.

Kaser, L. \& Halbert, J. (2009). Leadership mindsets: Innovation and learning in the transformation of schools. London, England: Routledge.

Kheswa, G. E. (2016). Exploring the contribution of spiritual intelligence to leadership in the public sector (Doctoral dissertation). University of South Africa, Pretoria.

King, D. (2008). Rethinking claims of spiritual intelligence: A definition, model and measure. (Master's thesis). Retrieved from http://www.davidbking.net/spiritualintelligence/thesis.pdf

King, D. B. \& DeCicco, T. L. (2009). A viable model and self-report measure of spiritual intelligence. International Journal of Transpersonal Studies, 28(1).

Kozol, J. (2012). Savage inequalities: Children in America's schools. New York, NY: Broadway Books.

Kramer, B. H. \& Enomoto, E. K. (2014). Leading ethically in schools and other organizations: Inquiry, case studies, and decision-making. Lanham, MD: Rowman \& Littlefield.

Kulkarni, V. \& Amale, J. (2015). Spiritually and emotionally intelligent leadership. Chronicle of the Neville Widia Institute of Management Studies and Research, 61-67.

Kumar, P. B. \& Muruganantham. (2015). Spirituality and entrepreneurial success of business in Madurai. International Journal of Research in Management, Science \& Technology, 3(4), 101-105.

Lichtman, M. (2012). Qualitative research in education: A user's guide: Thousand Oaks, CA: Sage.

Lin, C. S. (2013). Revealing the "essence" of things: Using phenomenology in LIS research. Qualitative and Quantitative Methods in Libraries, 4, 469-478

Lofaso, A. M. (2009). Religion in the public schools: A road map for avoiding lawsuits and respecting parents' legal rights. New York, NY: Americans United for Separation of Church and State.

Louth, A. (2007). The origins of the Christian mystical tradition: From Plato to Denys. New York, NY: Oxford University Press on Demand.

MacNeil, A. J., Prater, D. L., \& Busch, S. (2009). The effects of school culture and climate on student achievement. International Journal of Leadership in Education, 12(1), 73-84.

Macon, G. K., Sr. (2014). School leaders and spirituality: Perspectives of spirituality and spirituality's influence on principals in public schools in southeastern Louisiana. (Doctoral Dissertation).

Retrieved from ProQuest. (UMI1629017372)

Magnusen, C. L. (2001). Spiritual leadership in educational administration (Doctoral dissertation). Retrieved from ProQuest. (UMI3014209)

Maitlis, S. \& Christianson, M. (2014) Sensemaking in organizations: Taking stock and moving forward. The Academy of Management Annals, 8(1), 57-125. 
Mayer, J. D. (2000). Spiritual intelligence or spiritual consciousness? The International Journal for the Psychology of Religion, 10(1), 47-56.

McInerney, M. \& McKlindon, A. (2014). Unlocking the door to learning: Trauma-informed classrooms \& transformational schools. Education Law Center. Web. Unlocking the Door to Learning:

Trauma-Informed. Retrieved from http://www. elc-pa. org/wp-content/uploads/2015/06/TraumaInformed-in-Schools-Classrooms-FINAL-December2014-2. pdf.

Merriam, S. B. (2014). Qualitative research: A guide to design and implementation. Hoboken, NJ: John Wiley \& Sons.

Merton, T. (1972). New seeds of contemplation (Vol. 337). New York, NY: New Directions Publishing.

Moreno, L. (2015). A phenomenological study: An exploration into spiritual leadership as an added dimension to effective educational leadership and student achievement. (Doctoral dissertation). Retrieved from ProQuest. (UMI1727477619)

Morgan, E., Salomon, N., Plotkin, M., \& Cohen, R. (2014). The school discipline consensus report: Strategies from the field to keep students engaged in school and out of the juvenile justice system. New York: Council of State Governments Justice Center.

Moustakas, C. (1994). Phenomenological research methods. Thousand Oaks, CA: Sage.

Muhammad, A. (2009). Transforming school culture: How to overcome staff division. Bloomington, IL: Solution Tree Press.

Musu-Gillette, L., Robinson, J., McFarland, J., Kewal-Ramani., A., Zhang, A., \& Wilkinson-

Flicker, S. (2016). Status and trends in the education of racial and ethnic groups. Institute of Education Sciences, NCES 201-00, 1-169. Retrieved from: http://nces.ed.gov/pubs2016/2016007.pdf

Nasel, D. (2004). Spiritual orientation in relation to spiritual intelligence: A consideration of traditional Christianity and New Age/individualistic spirituality. (Unpublished doctoral dissertation), University of South Australia. Adelaide, SA.

National Education Association (2015). Understanding the gaps: Who are we leaving behind and how far? Retrieved from http://www.nea.org/assets/docs/18021-Closing_Achve_Gap_backgrndr_7FINAL.pdf

National Education to End Homelessness (2015). Issue brief: Commercial sexual exploitation of children (CESC) and youth homelessness. Retrieved from http://www.1800runaway.org/wpcontent/uploads/2015/05/National-Alliance-to-End-Homelessness-issue-brief.pdf

National School Boards Association. (2013). Addressing the out-of-school suspension crisis: A policy guide for school board members. Retrieved from https://cdn-files.nsba.org/s3fspublic/0413NSBA-

Out-Of-School-Suspension-School-Board-Policy Guide.pdf?mXctTtx3nmKnZ9TKWSY1upU7FBBiS2jN

Noddings, N. (2013). Caring: A relational approach to ethics and moral education. San Francisco, CA: University of California Press.

Noddings, N. (2015). The challenge to care in schools, 2nd Edition. New York, NY: Teachers College Press.

Noguera, P. (2003). City schools and the American dream: Reclaiming the promise of public education (Vol. 17). New York, NY: Teachers College Press.

O’Brennan, L. M., Waasdorp, T. E., \& Bradshaw, C. P. (2014). Strengthening bullying prevention through school staff connectedness. Journal of Educational Psychology, 106(3), 870.

Parker-Pope, T. (2008). Maternal instinct is wired into the brain. The New York Times. Retrieved from http://well.blogs.nytimes.com/2008/03/07/maternal-instinct-is-wired-into-the-brain/? $\mathrm{r}=0$

Patton, M.Q. \& Cochran, M. (2002). A guide to using qualitative research methodology. Retrieved from http://evaluation.msf.at/fileadmin/evaluation/files/documents/resources_MSF/MS F Qualitative Methods.pdf

Reyes, D. M. (2015). The role of spirituality in the decisions and actions of Latino principals (Doctoral dissertation). Retrieved from ProQuest. (UMI1751042151) 
Santovec, M. L. (2013). Emotional, spiritual intelligence create exemplary leaders. Women in Higher Education, 22(4), 1-2.

Satchidananda, S. S. (2000). The Living Gita. Buckingham, VA: Integral Yoga Publications.

Schnittjer, G. E. (2010). The Torah story: An apprenticeship on the Pentateuch. New York, NY: Harper Collins.

Seitz, R. J., Nickel, J., \& Azari, N. P. (2006). Functional modularity of the medial prefrontal cortex: Involvement in human empathy. Neuropsychology,20(6), 743.

Sergiovanni, T. J. (1999). Rethinking leadership. Arlington Heights, IL: SkyLight.

Šilingienè, V. \& Škèrienè, S. (2015). Expression of leaders' spiritual intelligence in a context of service organizations: A gender approach. Procedia-Social and Behavioral Sciences, 213, 758-763.

Singh, S., Swarup, A., \& Singh, R. (2015). Spiritual intelligence: A road map to future learning. International Multispecialty Journal of Health. 9(1), 1-8.

Sisk, D. A. (2015). Spiritual intelligence: Developing higher consciousness revisited. Gifted Education International, 32(3), 194-208. DOI: 10.1177/0261429415602567

Sorvaag, S. H. (2007). The spiritual orientation of K-12 public school principals. (Doctoral dissertation). Retrieved from ProQuest. (UMI304765210)

Starratt, R. J. (2004). Ethical leadership (Vol. 8). San Francisco, CA: Jossey-Bass

Starratt, R. J. (2005a). Responsible leadership. The Educational Forum, 69, 124-133.

Starratt, R. J. (2005b). Cultivating the moral character of learning and teaching: A neglected dimension of educational leadership. School Leadership and Management, 25(4), 399-411.

Stefkovich, J. A. (2013). Best interests of the student: Applying ethical constructs to legal cases in education. New York, NY: Routledge.

Stefkovich, J. A. \& O'Brien, G. M. (2004). Best interests of the student: An ethical model. Journal of Educational Administration, 42(2), 197-214.

Stolp, S. \& Smith, S. C. (1995). Transforming school culture: Stories, symbols, values \& the leader's role. (Doctoral dissertation). Retrieved from ProQuest. (UMI62636080)

Thapa, A., Cohen, J., Higgins-D’Alessandro, A., \& Guffey, S. (2012). School climate research summary: August 2012. School Climate Brief, 3, 1-21.

The Bible. (1996). New Living Translation. Chicago, IL: Tyndale House Publishers.

Walton, R. (2015). Precursor, indicator or mirage: What relationship exists between spirituality and type of giftedness? (Doctoral dissertation). Retrieved from http://ro.uow.edu.au/cgi/viewcontent.cgi?article $=5526 \&$ context $=$ theses

Weichel, K. \& Neal, J. (2014). Tapping your spiritual intelligence. Retrieved from http://www.judineal.com/pages/pubs/other_tapping.htm

Whitney, D. S. (2014). Spiritual disciplines for the Christian life. Chicago, IL: Tyndale House Publishers.

Zohar, D. (1997). Rewiring the corporate brain: Using the new science to rethink how we structure and lead organizations. Oakland, CA: Berrett-Koehler Publishers.

Zohar, D., Marshall, I. N., \& Marshall, I. (2000). SQ: Connecting with our spiritual intelligence. London, England: Bloomsbury Publishing. 